\title{
Memórias de uma professora ao recompor cenários do ensino público em Lomba Grande, Novo Hamburgo, RS (1931-1942)
}

JOSÉ EDIMAR DE SOUZA Universidade do Vale do Rio dos Sinos, São Leopoldo, RS, Brasil

LUCIANE SGARBI SANTOS GRAZZIOTIN Universidade do Vale do Rio dos Sinos, São Leopoldo, RS, Brasil

\section{RESUMO}

Este estudo analisa as narrativas de Gersy, uma professora do grau primário, cujas memórias ajudam a compreender como se constituíram os primeiros tempos de escolarização no espaço rural de Lomba Grande, Novo Hamburgo, RS. As práticas culturais, nesta pesquisa, pretendem recompor a história do ensino nesse local, entre o ingresso de Gersy na escola, como aluna, em 1931, até o início de sua vida profissional como professora, em 1940. Halbwachs (2006), entre outros autores, auxilia na articulação entre memória e contexto sócio-histórico reconstruído pela ótica da história cultural. $\mathrm{O}$ conjunto de indicadores empíricos evidencia um saber incorporado ao fazer docente naquela comunidade e a mobilização da comunidade para que os filhos dos colonos tivessem escola. Ao desenvolver os procedimentos analíticos, percebem-se também limites e possibilidades no uso da memória. Entre as conclusões, ainda permanece a questão: um grupo escolar em uma região rural germânica poderia estar associado à "política de nacionalização" que caracterizou o governo de Getúlio Vargas?

\section{PALAVRAS-CHAVE}

história da educação; memória; ensino rural; práticas pedagógicas; aula pública. 


\section{MEMORIES OF A TEACHER RECONSTRUCTING SCENARIOS IN PUBLIC EDUCATION IN LOMBA GRANDE, NOVO HAMBURGO, RS (1931-1942)}

\section{ABSTRACT}

This study analyzes narratives of Gersy, a school teacher whose memories help understanding about how schools were set up in rural areas of Lomba Grande, Novo Hamburgo, RS. Cultural practices in this research aim to reconstruct the history of education in this place, between the time when Gersy joins the school as a student in 1931 until the beginning of his life as a teacher in 1940. Halbwachs (2006), among others, helps link between memory and the socio-historical context rebuilt from the perspective of cultural history. The set of empirical indicators shows a knowledge embedded in that community to make teaching and community mobilization for the children of the settlers who had school. In developing the analytical procedures are perceived limits and possibilities also in memory usage. Among the conclusions, the question still remains: could the school group in a rural area in German be associated with the "nationalization policy" that characterized the government of Getúlio Vargas?

KEYWORDS

history of education; memory; rural education; teaching practices; public school.

\section{MEMORIAS DE UNA MAESTRA AL RECOMPONER ESCENARIOS DE LA EDUCACIÓN PÚBLICA EN LOMBA GRANDE, NOVO HAMBURGO, RS (1931-1942)}

\section{RESUMEN}

Este estudio analiza las narrativas de Gersy, una maestra de la escuela primaria cuyas memorias ayudarán a entender cómo se construyeron los primeros tiempos de escolarización en las zonas rurales de Lomba Grande, Novo Hamburgo, RS. Las prácticas culturales, dentro de esta investigación, pretenden recomponer la historia de la enseñanza en este lugar, desde la admisión de Gersy en la escuela, como alumna en el año 1931 , hasta el comienzo de su vida profesional como profesora, en 1940. Halbwachs (2006), entre otros autores, auxilia la articulación entre la memoria y el contexto sociohistórico reconstruido desde la perspectiva de la historia cultural. El conjunto de indicadores empíricos evidencia un conocimiento integrado al hacer docente en aquella comunidad y la movilización de la misma para que los hijos de los colonos tuvieran escuela. Al desarrollar los procedimientos analíticos se perciben, también, los límites y posibilidades en el uso de la memoria. Entre las conclusiones, la pregunta continúa siendo: un grupo escolar en una región rural germánica podría estar asociado a la "política de nacionalización" que caracterizó el gobierno de Getúlio Vargas?

historia de la educación; memoria; enseñanza rural; prácticas pedagógicas; escuela pública. 


\section{[...] tinha naquele tempo quatro [pausa] escolas. [...] Duas escolas estaduais: uma do meu pai - José Afonso e de D. Julieta Bohrer [...]. \\ Depois, as duas: da comunidade católica e outra de comunidade evangélica - que é logo aqui embaixo - [...]. Esta da comunidade, a professora Alfrídia Enck e o professor Alfredo Kunrath da escola católica. [...] Estes eram os professores ${ }^{1}$ daquele tempo [...].}

Thiesen, 2010

\section{INTRODUÇÃO}

Em história, tudo começa com o ato de separar, de organizar e de transformar em "[...] documentos determinados objetos repartidos de outra maneira" (Certeau, 2011, p. 69). Este texto expõe reflexões construídas a partir da investigação de mestrado realizado no Programa de Pós-Graduação em Educação da Universidade do Vale do Rio dos Sinos (UNISINOS). ${ }^{2}$ Especificamente, utiliza memórias de uma professora - repartidas de outra maneira - sobre seu tempo de estudante até o momento em que inicia sua vida de professora. A categoria de memória é analisada no sentido ao qual atenta Halbwachs (2006), percorrendo-se fragmentos que permitiram conhecer e compreender um pouco mais sobre as práticas de ensino no espaço rural de Lomba Grande, destacados pela professora Maria Gersy Höher Thiesen. ${ }^{3}$

Muitos historiadores, a partir do seu recorte teórico e metodológico, empenham-se em demarcar etapas nítidas ao longo dos tempos, identificando especificidades no processo histórico que analisam. A história da educação, orientada pela perspectiva da história cultural, tem evitado demarcações rígidas, preferindo explorar a diversidade de elementos empíricos em locus específicos, sem, obviamente, deixar

$1 \mathrm{Na}$ Chamada (1930, p. 85), consta o nome desses professores como segue: "Dia 29 de julho de 1940, Segunda-feira - Número, Nome do professor, Cargo, Hora de saída, Observações”. Transcrevo as mais significativas: “[...] José Afonso Höher, Cargo Regente. [...] Alfrídia Enck, Cargo - Prof. Mun. [...] Pedro Alfredo Kunrath - Prof. Mun. [...] Gersy M. Höher - Auxiliar [...] Julieta B. Gerhardt”. Portanto, havia duas aulas municipais regidas pelos professores: Alfrídia e Pedro; uma federal regida pelo professor José Afonso; e uma aula estadual regida pela professora Julieta. Maria Gersy era professora auxiliar contratada pelo município. Quanto à trajetória docente dos professores municipais, consta: "Pedro Alfredo Kunrath [...] Data de Nascimento 24 de novembro de 1907 [...] Estado Civil: Casado [...] Nomeado por ato No 16, de 11 de maio de 1940 para o cargo de professor [...]" (Registro, 1945, p. 220).

2 Trajetórias de professores de classes multisseriadas: memórias do ensino rural em Novo Hamburgo/RS (1940 a 2009), 2011. Dissertação orientada pela professora doutora Luciane Sgarbi Santos Grazziotin e co-orientada pela professora doutora Beatriz Terezinha Daudt Fischer. A investigação recebeu apoio do Fundo de Pesquisa Padre Milton Valente.

3 O sujeito desta pesquisa é identificado conforme termo de consentimento autorizado. Thiesen é sobrenome de casamento. 
de lado o contexto temporal. A história regional, por exemplo, representa um campo empírico rico, ainda não suficientemente explorado entre nós, como é o caso de pesquisas mais aprofundadas sobre o ensino público em horizontes rurais - objeto do qual também se tratará neste estudo.

A professora Maria Gersy, ao rememorar seu tempo de aluna na Aula Pública Mixta ${ }^{4}$ Federal, contextualiza a região central do bairro Lomba Grande, a década de 1930 e as respectivas escolas que existiam, como se observa na epígrafe. O recorte temporal neste estudo (1931 a 1942) consiste justamente em compreender as transformações que se processaram nessa região rural $^{5}$ nesse curto espaço de tempo.

Lomba Grande é um bairro do município gaúcho de Novo Hamburgo, em destaque na Figura 1, localizado na microrregião do Vale do Sinos. Ocupa uma área de $222,35 \mathrm{~km}^{2}$ e tem uma população de aproximadamente 240 mil habitantes. Limita-se com Campo Bom, Dois Irmãos, Estância Velha Gravataí, Ivoti, São Leopoldo, Sapiranga, Sapucaia do Sul e Taquara (Souza, 2012b). Situado aproximadamente a $50 \mathrm{~km}$ da capital Porto Alegre, representa uma das maiores redes municipais de ensino com aproximadamente 26 mil alunos e 1.600 professores em 76 escolas de ensino fundamental e educação infantil (Rocha, 2012).

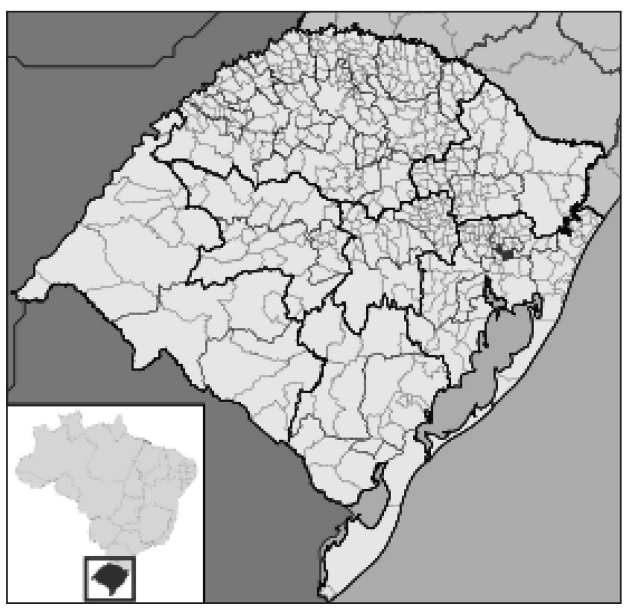

Figura 1 - Mapa de Novo Hamburgo, Rio Grande do Sul. Fonte: Souza (2012b, p. 13). Elaboração dos autores.

4 Tratando-se de uma investigação histórica, optou-se por preservar a forma de escrita original em todo este texto.

5 Este trabalho não pretende discutir trajetórias para o campo ou no campo como tratam, por exemplo, Ribeiro (2008), portanto (zona, espaço, meio, área) é lugar de contexto em que as memórias e práticas emergiram e foram analisadas. Sobre esse assunto, consultar também Almeida $(2001,2007)$. A literatura recente sobre o tema mostra a emergência do conceito de educação do campo, que se contrapõe à visão tradicional de educação rural. O espaço não se define, necessariamente, pela sua configuração física, porém se refere a sua multiplicidade, à referência construída e às suas filiações identitárias (Nóvoa, 2005). 
O referido município, até sua emancipação, pertencia a São Leopoldo e tem, entre as etnias que constituíram tal comunidade, contribuições expressivas dos alemães. A emancipação político-administrativa ocorreu em 5 de abril de 1927, porém Lomba Grande somente foi anexada à sede municipal em 2 de janeiro de $1940^{6}$ (Novo Hamburgo, 1940a). Dessa maneira, ao investigar os primórdios do ensino público nessa localidade no primeiro quartel do século $\mathrm{XX}$, recorre-se à relação "global/local” (Burke, 2005) das políticas educacionais na caracterização do contexto histórico e educacional.

Este texto está organizado em quatro partes, além da introdução. A primeira seção atenta aos usos da memória, bem como apresenta as "lentes investigativas" (Fischer, 2005) pelas quais se elaboram as construções desta escrita. Em seguida realiza-se a estruturação do contexto de ensino público em Novo Hamburgo. Os dois últimos tópicos referem-se às memórias de práticas que permitiram reconstruir uma história do ensino público para esse lugar, bem como as considerações finais.

\section{LENTES TEÓRICAS E METODOLÓGICAS}

A história é uma prática. Ela não é simples fala nobre de uma interpretação desencarnada e desinteressada. Pelo contrário, ela é sempre mediatizada pela técnica, pelas lentes curiosas do investigador no processo de transformação entre o documento e sua construção (Dosse, 2004). A prática da pesquisa histórica vai além do estudo das ações dos homens pertencentes aos círculos do poder civil, religioso, militar etc. Ela também inclui testemunhos anônimos, deixados por todos aqueles que interagem e negociam, direta e indiretamente, com as diferentes esferas sociais (Borges, 2011).

A história oral, como todas as metodologias, estabelece e ordena procedimentos de trabalho, funcionando como ponte entre teoria e prática, sendo apenas capaz de suscitar, jamais solucionar questões; formula as perguntas, porém não pode oferecer respostas. Pois apenas a teoria da história conseguirá responder à problematização construída, sendo que é a teoria que oferece os meios para refletir sobre o conhecimento, embasado no trabalho dos historiadores (Amado; Ferreira, 2002).

Compartilha-se, nesta pesquisa, a perspectiva da história cultural de Roger Chartier (2002, p. 16-17), quando ele afirma que essa abordagem tem "[...] por principal objeto identificar o modo como em diferentes lugares e momentos uma

6 O referido decreto assinala: "O Prefeito Municipal de Novo Hamburgo, no uso das atribuições que the confere o $\operatorname{art}^{\circ}$ 12, n. 2, do Decreto-Lei Federal n. 1.202, de 8 de abril de 1939, e, ainda, em face do Decreto n. 7.842, de 30 de junho de 1939, do Governo do Estado; considerando que toda area do antigo $6^{\circ}$ Distrito designado Lomba Grande e outras frações territoriais do municipio de São Leopoldo, discriminadas e fixadas no aludido Decreto Estadual, foram anexadas a este municipio [...] Decreta: Art. $1^{\circ}$ - Instala-se hoje mais um distrito neste municipio com a designação de Lomba Grande, integrando-se o seu territorio com a area anexada pertencente ao municipio de São Leopoldo entre os arroios Prazeres e Peão [...]” (Novo Hamburgo, 1940a). 
determinada realidade social é construída, pensada e dada a ler”. E também quando o autor esclarece:

As percepções do social não são de forma alguma discursos neutros: produzem estratégias e práticas [sociais, escolares, políticas] que tendem a impor uma autoridade à custa de outros, por elas menosprezada, a legitimar um projecto reformador ou justificar, para os próprios indivíduos, as suas escolhas e condutas [...]. (idem, p. 17)

As pesquisas sobre culturas e práticas escolares, desde o final dos anos 1990, têm dividido pesquisadores, principalmente quanto à seguinte questão: a escola seria produtora de uma cultura própria? Destacam-se, nesse sentido, os estudos realizados por:

[...] Diana Vidal [que] enfrenta a discussão acerca dos "usos e abusos" das concepções sobre cultura escolar [...] convoca alguns autores [...] dentre eles, André Chervel (1990), que enfatiza a singularidade, a originalidade da cultura escolar e a capacidade inventiva do sistema escolar [...]. (Cury, C. E., 2010, p. 44)

Entendendo que as práticas são criadoras de formas apropriadas pelas quais os sujeitos "inventam uma cultura escolar", desse modo, a partir das memórias sobre seu tempo de estudante e quando inicia sua trajetória de professora, questiona-se: como o ensino público foi constituindo-se em Lomba Grande? De que modo a comunidade se articulou para que houvesse escola para os filhos dos colonos? A evidência do Grupo Escolar em uma região rural germânica poderia estar associada à "política de nacionalização" da "Ditadura de Vargas" (Gertz, 2005)?

Quanto aos estudos de memória, é necessário registrar que, não sendo a história, é um dos seus indícios que pode ser transformado em documentos e de que se serve o historiador para produzir leituras do passado, do vivido pelos indivíduos, daquilo de que se lembram e se esquecem a um só tempo, produzindo no presente determinadas versões do passado. Prins (1992) complementa quando afirma que toda história depende de seu propósito social, e a história oral é a que melhor reconstrói as particularidades triviais das vidas das pessoas comuns.

Thomsom (1997) e Amado (1995) argumentam que a experiência como prática vivida, que remete à concretude da experiência de um indivíduo ou de um grupo social, constitui um substrato da memória que se reelabora constantemente, ou seja, nunca termina. As narrativas, segundo Amado (idem), retratam um cenário considerando que, ao trazer o passado até o presente, recria-o à luz do presente, ao mesmo tempo em que o projeta no futuro. Stephanou (2011, p. 11-12), sobre isso, afirma: "escrevemos e dizemos o que pensamos ter vivido, o que pensamos ter sentido, o que imaginamos ter experimentado”. A memória, portanto, constitui-se em uma entre as muitas possibilidades interpretativas para se ler a realidade - neste estudo, os primórdios do ensino público primário em Lomba Grande.

Aplica-se nesta investigação, além da história oral, a análise documental sob a ótica da história cultural (Chartier, 2002). Dessa forma, a cultura representa um conjunto de significados partilhados e construídos para compreender e conhecer um pouco 
sobre a evidência das aulas nas comunidades rurais, como prática que caracteriza o contexto do ensino público primário no Brasil no início do século XX.

As entrevistas transcritas aqui são tomadas como documento e servem para refletir e compreender o passado, também ao lado de outros documentos escritos, imagens e demais tipos de registro encontrados ao longo da investigação. A partir da análise documental, buscou-se identificar o modo como em diferentes lugares e momentos uma determinada realidade social é construída a partir do cruzamento de aspectos que emergiram na construção dos documentos orais e na organização das informações de diferentes naturezas (documentos orais, escritos e icnográficos).

Além das fontes documentais (análise de memórias orais e fotografias), utilizaram-se fragmentos de jornais na pesquisa, no sentido ao qual atenta Pimentel (2001), ponderando análises presentistas, evitando, de um lado, a ratificação do passado, e de outro, a glorificação do presente. $O$ trabalho utilizando jornais é fruto de mudanças na compreensão do documento e da própria história. O refletir acerca do noticiado, não o encarando como algo absolutamente verídico, sem contestações, precisa ser considerado. Sublinha também que o fato de ser questionado o "grau de veracidade" de uma matéria jornalística, ou de uma notícia, não diminui o valor do jornal diante do conteúdo que expressa (Galves, 2004). São as "lentes", definidas pelo historiador, que, a partir de documentos construídos, recompondo-os, farão o desenho da história, involuntariamente omitindo partes, ou extrapolando fatos, ou mesmo contando fragmentos de um todo maior.

\section{CONTEXTO DO ENSINO RURAL NA PRIMEIRA METADE DO SÉCULO XX}

Este estudo pretende, mesmo que de modo fragmentado, compreender e conhecer um pouco de cultura escolar produzida na Aula Pública e Comunitária de Lomba Grande entre 1931 e 1942. Entre os historiadores da educação brasileira há um renovado interesse pela história do ensino primário, principalmente sobre a escola pública primária no Brasil. No entanto, quanto a sua problematização, as investigações não têm contemplado o âmbito das práticas, da organização e funcionamento das instituições educativas. Esse aspecto ressalta o argumento de Souza (2006, p. 111) de que "[...] tornam-se imprescindíveis os estudos em cultura escolar que possam explicitar as diversas dimensões do funcionamento interno da escola em sua relação com a sociedade [...]”.

$\mathrm{Na}$ primeira metade do século XX, principalmente a partir de 1915, ocorreram campanhas e realizações por meio da educação e que pretendiam combater o analfabetismo, difundir a educação primária, defender o patriotismo, entre outras ações que primavam pela difusão da educação no Brasil. As mudanças econômicas e sociais promoveram transfigurações identitárias e, portanto, afirmou-se uma tendência de construção de identidades urbanas, associando a cidade ao status de progresso (Almeida, 2007). No entanto, a questão fundamental da escola continuava sendo de saber ler, escrever e contar. A função da instrução salientava-se diante dos 
novos paradigmas que se projetavam na ótica da formação geral e do desenvolvimento humano como sujeito pátrio, ativo e atuante (Ghirardelli Júnior, 2009).

A educação rural foi vista como um instrumento capaz de formar, de modelar um cidadão adaptado ao seu meio de origem, mas lapidado pelo conhecimento científico endossado pelo meio urbano. A escolarização deveria preparar e instrumentalizar o homem rural para enfrentar as mudanças sociais e econômicas. Dessa forma, o sujeito do campo poderia participar e compreender as ideias de progresso e modernidade que emergiam no país.

Para Almeida (2006), a reconfiguração da sociedade brasileira que se estruturava a partir da República desejava-se progressista e esclarecida, com o potencial de regeneração nacional. Havia a crença em uma visão de escola doméstica, que cuida, ampara, ama e educa. No período de nossa história designado de República Velha, há considerável incremento das escolas públicas. O ensino privado, contudo, experimentará seu período áureo sob a égide do Positivismo e seu peculiar posicionamento em relação ao ensino. O período foi, por outro lado, tempo de gestação de nacionalismo, que se faria sentir de modo especial na Era Vargas, quando o Estado totalitário, criando inimigos para se manter no poder, lançou-se implacável sobre o ensino privado e, em especial, sobre as escolas comunitárias, ${ }^{7}$ das quais só poucas resistiriam após o final do período (Dreher, 2008). Esse aspecto favoreceu que aulas (escolas públicas), sob o controle do governo do Estado, no Rio Grande do Sul, fossem instituídas.

A intensa preocupação dos governantes, do governo gaúcho e, posteriormente, do federal, entre 1930 e 1945, nas regiões coloniais (germânica e italiana) foi imprimir uma identidade nacional a partir da escola, e esse fato contribuiu para que em Lomba Grande as Aulas Isoladas fossem instaladas em diferentes localidades.

A história de Novo Hamburgo está imersa no contexto da colônia alemã de São Leopoldo, principalmente a religião luterana e católica, que, no decorrer do século XIX, colaborou para a constituição e origem das vilas no Vale do Sinos (considerando o estabelecimento de colonos ao longo do rio do Sinos).

No século XVIII, em razão de a localidade estabelecer limite geográfico com Gravataí e Viamão, a região servia de rota dos tropeiros que direcionavam o gado sulino para região Sudeste do país e que

[...] de certo modo, também contribuíram para a história da cultura escolar deste lugar. Se por um lado, a presença portuguesa não foi capaz de constituir um lastro cultural tão forte quanto as raízes do status de vila (legado dos alemães na segunda metade do século XIX), a memória das "Aulas" sobreviveu à cronologia do tempo. (Souza; Fischer, 2012, p. 2)

7 Arendt (2008) ainda argumenta que o papel das escolas rurais tem sido apresentado, por vezes, na historiografia, com uma visão laudatória. Gertz (2005) polemiza sobre as produções "reducionistas" e que não compreendem a variável étnica a partir de "lógicas universais". Não existe um consenso quanto a sua forma e prática, algumas até mesmo apresentavam condições de trabalho bastante precárias e insuficientes. 
As marcas culturais da presença germânica nesse município registram os primórdios do que podemos chamar processo de escolarização pública (idem). Como em muitas comunidades no Brasil que foram colonizadas pelos alemães, as vilas foram surgindo a partir da abertura de picadas, que eram trilhas de acesso a uma propriedade. Com a instalação das famílias de colonos, surgiram os templos (católico ou luterano, aos quais pertenciam imigrantes alemães), a escola (tradição trazida pelos imigrantes), o cemitério, a residência do professor ou do padre/pastor e o salão de festas comunitárias (Dreher, 2008).

A vida em comunidade e a reprodução cultural dos costumes europeus abaixo da linha do Equador caracterizaram-se pela experiência da agricultura, dos trabalhos liberais e da escola comunitária. As escolas comunitárias, também conhecidas como Aulas, compunham o cenário das comunidades germânicas, ao lado da igreja e do cemitério.

\section{MEMÓRIAS DE PRÁTICAS RECOMPONDO CENÁRIOS DE ENSINO PÚBLICO EM LOMBA GRANDE}

Nesta seção, o texto estrutura-se de modo que reconstrua, mesmo que de forma fragmentada, ${ }^{8}$ o processo de escolarização constituído em Lomba Grande, bem como se entrelaça às memórias dos primeiros tempos de escola e início da docência da professora Maria Gersy.

O percurso de vida e profissional da professora Gersy desenvolveu-se em Lomba Grande. Quando nasceu, em 18 de março de 1924, na localidade de Rosenthal (Roseiral), atual localidade de Santa Maria, o lugar era distrito do município de São Leopoldo. Maria Gersy Höher Thiesen é filha do professor José Afonso Höher e da escrivã Erna Olinda Höher (Souza, 2012a).

A história de escolarização $9^{9}$ no município antes da emancipação, em 1927, vincula-se à história da educação de São Leopoldo. Novo Hamburgo, segundo distrito

8 Nesta seção estão incluídas as construções e/ou análises que compõem a escrita da tese de doutorado defendida em janeiro de 2015 na UNISINOS.

9 A preparação de um "estado da arte" permitiu reconhecer que nos últimos cinco anos os estudos sobre a história local/regional demonstram pouco interesse pelos estudos da cultura rural no Vale do Sinos. Como lembra Schemes (2006), a história dos municípios ainda não representa uma prática comum dos historiadores brasileiros, por isso os acontecimentos se perdem e fica muito difícil reconstituir períodos mais distantes. Quanto à bibliografia sobre Novo Hamburgo, destacam-se os estudos (monográficos) de Petry (1959), Schültz (2001) e, mais recentemente, as teses de doutorado de Schemes (2006) e Martins (2011). Ambos demonstraram preocupação com a recuperação historiográfica. Porém nenhum específico sobre Lomba Grande. Além desses, Selbach (1999) pesquisa sobre os processos de urbanização no município, na dissertação de mestrado desenvolvida na Faculdade de Arquitetura da Universidade Federal do Rio Grande do Sul. Contudo, destaca-se o trabalho de Werle (2005), que, pesquisando sobre a cultura escolar em âmbito nacional/local, recupera importante documentação sobre as políticas educacionais, principalmente em São Leopoldo. Quanto às histórias de professoras primárias em Novo Hamburgo, esta pesquisa desdobra-se, com base nos estudos de Fischer (2005), na perspectiva que 
de São Leopoldo, registra uma forma artesana ${ }^{10}$ de organização do ensino até a década de 1950. Entendêmo-la desse modo, pois a escolarização dava-se pela articulação entre a comunidade e a pequena participação e investimento na educação por parte do Estado, como ente público.

Quanto aos investimentos para o ensino público primário, entre o final do século XIX e as primeiras décadas do século XX, a contribuição federal era quase insignificante. A gestão da Aula Pública era realizada pelos estados da Federação, e os recursos chegavam aos municípios por meio de subvenções. Esse aspecto favorecia certa autonomia docente, principalmente nas aulas (escolas isoladas). Se no período do Estado Novo de Vargas havia pretensão de se constituir uma unidade educacional federal em favor de um regime único (Baia Horta,2010), somente após o período ditatorial do Estado Novo é que se "[...] repõe em termos federativos a autonomia dos Estados na organização dos sistemas de ensino" (Cury, 2009, p. 25).

Quanto à presença das “aulas" em Lomba Grande - o que foi possível localizar até o momento -, havia uma Aula Pública em $1863,{ }^{11}$ em pleno Segundo Império. No entanto, a comunidade evangélica de Lomba Grande foi fundada em 8 de fevereiro de 1842, e sabe-se que desde 1834, em um antigo prédio que servia às pregações dos "cura de almas", também acontecia a alfabetização dos filhos dos colonos.

É provável que nessa aula de alfabetização fossem utilizadas as "cartilhas" manuscritas que foram elaboradas por Rosenboeck, professor de Hamburgo Velho (Kreutz, 2002). Além disso, outra professora que constitui os sujeitos da pesquisa, ao rememorar o tempo de escola de sua avó, "Hermínia Felipina Bomm", foi aluna da Escola da Comunidade Evangélica entre 1885 e 1895, e ela utilizava uma cartilha de gramática e de calcular ${ }^{12}$ (Bohrer, 2010).

documenta narrativas orais do ensino rural nesse município. Para um estudo mais recente sobre as memórias das práticas educativas durante o Primeiro Governo Vargas, que enfatiza a escolarização no espaço urbano, ver Kerber, Schemes e Prodanov (2012).

10 Na pesquisa desenvolvida no citado curso de mestrado, o período de 1940 a 1970 é caracterizado como "primeiros tempos", cuja docência esteve vinculada à ideia de tradição de família, entrecruzada com a representação docente como um "apostolado missionário", sob forte influência da Igreja cristã católica. Além disso, as trajetórias amarraram práticas que relacionam contexto local e história institucional de escolarização (Souza, 2012b).

11 Documento em alemão gótico, localizado no acervo virtual particular de Moisés Braun, em 2011. De acordo com a transcrição do professor Martin Dreher: "Aula Pública de Lomba Grande. $1^{\circ}$ lugar. Fita de seda vermelha com borda de crochê, concedida e conferida à aluna Wilhelmine Burger como recompensa por seu extraordinário esforço e excelente comportamento, bem como incentivo para que assim continue, na oportunidade do exame prestado no corrente ano, por seu professor Heinrich Meyer. Lomba Grande, aos 16 de dezembro de 1863". Dreher complementa que o texto é de autoria do professor Heinrich Meyer (Brummer), mercenário contratado pelo Império na guerra contra Rosas. Atuou na Aula Pública de Lomba Grande e, por isso, deve ter sido nomeado pelo Governo Provincial (Souza, 2012b).

12 Kreutz (2002) indica a utilização da cartilha Neuestes ABC-Buchstabier-und Lesebuch zunächst die Kolonie Von S't Leopoldo (o mais novo abecedário para aprender a soletrar e a ler na colônia de São Leopoldo), impresso a partir de 1832 e utilizado pelos professores nas escolas comunitárias. 
Quanto à igreja evangélica de Lomba Grande, prédio de material, foi fundado em 8 de fevereiro de 1842. Antes disso "[...] existia um edifício de barro, iniciado em 1834, destinado ao funcionamento de uma escola e onde também se realizava o serviço litúrgico da comunidade evangélica [...]” (O 5 de Abril, 1948, p. 1). Em virtude da Revolução Farroupilha, somente em 1842 a igreja pôde ser concluída, ano em que foi inaugurada pelo pastor Ehlers. É provável que esse tipo de escola identifique-se com as escolas comunitárias germânicas, estudadas principalmente por Kreutz $(2001,2009)$ e Luchese e Kreutz (2012).

A escola da comunidade evangélica de Lomba Grande, fundada nesse mesmo ano de 1842, serviu à alfabetisação da juventude dessa terra, ininterruptamente, durante 98 anos, isto é, até 1940. [...] Como lembrança valiosa da festa, foi exposto à venda um fasciculo ricamente ilustrado em otima impressão, contendo uma resenha historica da vida da comunidade, bem como numerosas fotografias oferecidas pelo s. Germano Stumpf, filho de Lomba Grande e proprietário de um conhecido atelier fotográfico em S. Leopoldo. (O 5 de Abril, 1948, p. 4)

O Quadro 1, elaborado especialmente para este texto, auxilia na compreensão do processo de escolarização nesse lugar, referindo-se ao ensino que acontecia, além daquele realizado em casa e na roça pelos pais.

Quadro 1 - Escolas de Lomba Grande: região central do bairro* (1863 a 1942)

\begin{tabular}{|l|l|l|}
\hline \multicolumn{1}{|c|}{ Nome } & \multicolumn{1}{|c|}{ Data } & \multicolumn{1}{c|}{ Observação } \\
\hline Escolas Comunitárias & 1834 & O 5 de Abril, de 20 de fevereiro de 1948. \\
\hline Aula Pública de Lomba Grande & $1863-1864$ & $\begin{array}{l}\text { Documento em alemão gótico localizado } \\
\text { em 2011. Ver Souza (2012b). }\end{array}$ \\
\hline Aula da Comunidade Evangélica & $\begin{array}{l}1913-1915 \\
1927 \text { a 1934 } \\
1935 \text { a 1939 }\end{array}$ & $\begin{array}{l}\text { Sobre o período de 1915 a 1927, ainda } \\
\text { não foi localizado nenhum documento. }\end{array}$ \\
\hline Aula da Comunidade Católica & 1931 & Werle (2005) e Thiesen (2010).** \\
\hline Aula Pública Mixta Federal & $1917-1921$ & $\begin{array}{l}\text { O registro encontra-se no arquivo passivo } \\
\text { da EMEF José de Anchieta, na localidade } \\
\text { de São João do Deserto, Lomba Grande. } \\
\text { Ver Souza e Grazziotin (2012b). }\end{array}$ \\
\hline Aulas Reunidas Municipais e Estaduais & $1931-1937$ & Ver O 5 de Abril (1940a); Thiesen (2010). \\
\hline Escolas Reunidas n 5 & $1939-1940$ & Thiesen (2010). \\
\hline Grupo Escolar de Lomba Grande & 1940 & Thiesen (2010). \\
\hline Grupo Escolar Madre Benícia & $\begin{array}{l}\text { Fundado em } \\
14 / 3 / 1942\end{array}$ & $\begin{array}{l}\text { Essa instituição ainda existe } \\
\text { atualmente com o nome de Instituto } \\
\text { Estadual Madre Benícia. }\end{array}$ \\
\hline
\end{tabular}

* Não foram consideradas as Aulas Isoladas, Avulsas que existiram nesse período. Contudo, destaco a fundação da Aula Pública Mixta do "Morro dos Bois" em 1933 e da Aula Bento Gonçalves em 1894, na localidade de Taimbé.

** Registro presente nas memórias de Thiesen (2010), entre as décadas de 1930 e 1940. Durante a procura pelos registros dessa Aula, a secretaria da igreja informou que, na década de 1990, o padre da paróquia São José de Lomba Grande incinerou os documentos que havia no arquivo dessa igreja sobre a escola. 
Sobre a escola da comunidade evangélica, localizaram-se alguns livros de frequência de alunos. $\mathrm{O}$ referido documento é um conjunto de folhas com traçados de linhas, parecido com o papel almaço pautado, cuja "[...] folha dobrada ao meio (costurado), dá quatro laudas de $33 \times 22 \mathrm{~cm}$, dimensões exigidas para correspondência oficial" (Acioli, 1994, p. 11). A documentação segue uma característica formal, evidenciando cuidado com a forma e a apresentação. Registra caligrafada no tipo cursivo e sobre papel traçado de linhas. As vinte e nove folhas que constituem esse documento são numeradas e rubricadas pelo senhor João Schmitz. Na contracapa registra-se:

Este livro servirá para si elle lançarem-se o livro de chamada dos alunnos da Aula Municipal Mixta da Lomba Grande, $6^{\circ}$ Distrito de São Leopoldo, contem 29 folhas numeradas e por mim rubricadas com a rubrica Schmitz de que uso e levo em fim o competente termo de encerram este. Lomba Grande, $1^{\circ}$ de agosto de 1913. O membro escolar João Schmitz. (Livro..., 1913)

O início do ano letivo de 1913 nessa escola começa em julho e encerra-se em 19 de dezembro. Em 1914, as aulas iniciaram em 14 de janeiro e foram encerradas em 19 de dezembro. $\mathrm{O}$ ano de 1915 está incompleto. As aulas iniciaram em 7 de janeiro de 1915, e o livro encerra-se em 3 de julho do mesmo ano. Nos outros anos, o dia 14 de julho ${ }^{13}$ consta como feriado. Os alunos estão organizados por gênero, sendo o registro do nome dos meninos de um lado e das meninas de outro, mesmo havendo a "coeducação" (Schimmelpfeng, 2005, p. 156). Contabilizam-se 58 alunos, sendo 31 meninos. Entre os alunos: Oscar Beck, Hilda Scherer, Ilse Nabinger, Helma Muller.

Outro documento refere-se ao período de 1927 a 1934. Nessa época, o professor responsável era o pastor Sauer. Na primeira página registra-se uma alteração: a Aula passava a ser particular, ou seja, atendendo apenas aos alunos da comunidade evangélica. "Aula particular da Comunidade da Evangélica localisada na Lomba Grande, VI districto de São Leopoldo. Professor: em branco e a lápis Jacob Sauer" (Aula, 1927, p. 1). Destaca-se a rotatividade de professores no ano letivo de 1927, como consta "[...] do mez de jan - abril 1927 [P. Kaiser]/ Maio[P. Sauer]/ junho, Agosto/[H. Pfeifer]/ Setembro. Novembro [H. Imke]/Dezembro [Ilse Nabinger] [...]" (Aula..., 1927). O registro de frequência e apontamentos sobre a vida escolar dos alunos está em alemão gótico. Em 1934, a professora Iva Muller passa a reger a classe das meninas.

Ainda sobre a aula da comunidade evangélica, localizou-se outro livro de chamada, que compreende o período de 1935 a 1939. Trata-se de um livro de capa preta impresso pela Rotermund \& Co., de São Leopoldo, cujo título de capa é "Chamada".

13 Festa Pan-Americana. Identificam-se duas datas de comemoração. Nos cadernos de chamada das Aulas da comunidade evangélica de Lomba Grande, de 1913-1939: 14 de julho - Dia Nacional dos Povos Americanos; e a data 14 de abril - Dia Mundial da Liberdade. Esta última, no jornal 05 de Abril é registrada como Dia das Américas, festa e feriado pan-americano. 
Esse livro de chamada da aula da comunidade evangélica ressalta a docência do professor José Afonso Höher, entre maio de 1937 e fevereiro de 1938. Em julho de 1939, quando as aulas da região central foram reunidas para constituir o grupo escolar, os professores eram Alfrídia Enck e Jacob Sauer.

Na década de 1920, o professor José Afonso Höher atuava como professor itinerante com sua Aula Pública Mixta Federal, circulando pelo bairro Lomba Grande. No arquivo passivo da Escola Municipal de Ensino Fundamental José de Anchieta, na localidade atual de São João do Deserto, encontra-se um livro de chamadas com assinatura do professor José Afonso Höher entre os anos de 1917 e 1921, como se observa na Imagem 1.

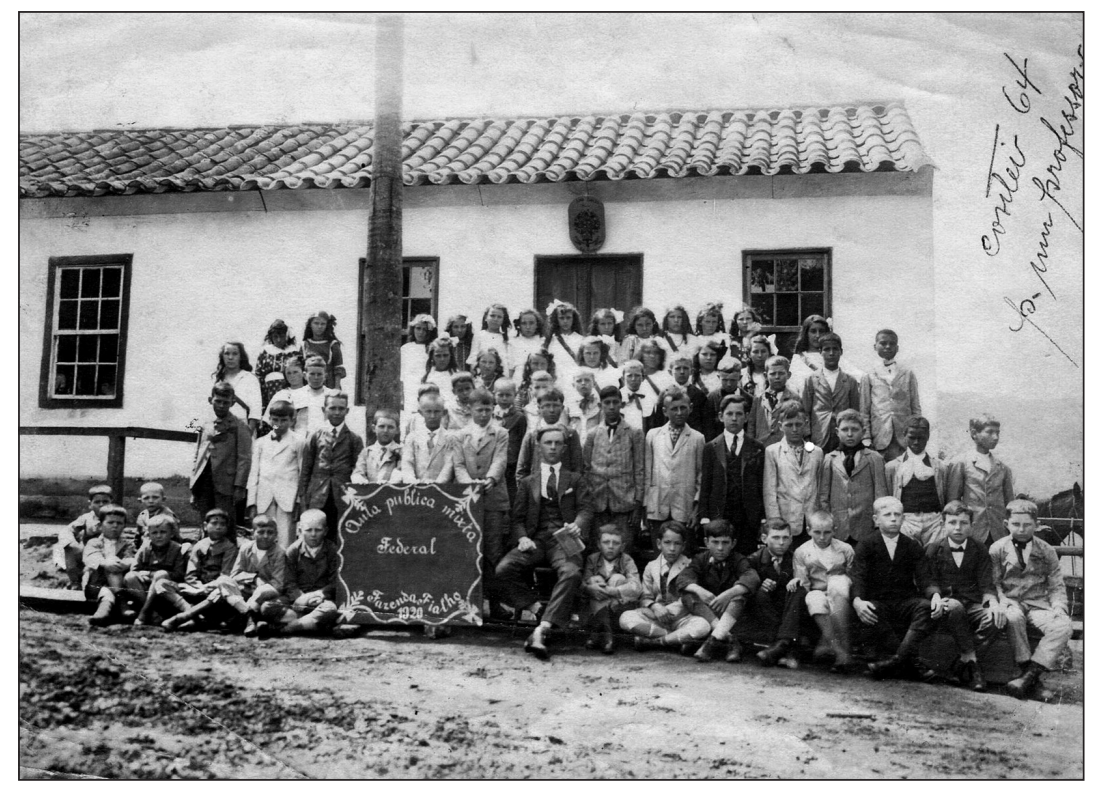

Imagem 1 - Aula federal (1920).

Fonte: Acervo particular da professora Maria Gersy Höher Thiesen (2010).

Sobre esse fato, Gersy rememora que "[...] o pai ficava afastado semanas e seguia diferentes caminhos a cavalo [...]” (Thiesen, 2010). Ela ainda adorava escutar as muitas histórias que ele costumava contar quando retornava para casa. Na Imagem 1 registra-se: "Aula Pública Mixta Federal em 1920, Fazenda Fialho", situada na divisa entre Lomba Grande e Taquara. Na década de 1930, essa aula funcionava na região central de Lomba Grande, como se percebe adiante.

Quanto às aulas da comunidade católica, Werle (2005) registra um pedido de subvenções, realizado pelo professor José Afonso Höher, feito em nome da comissão examinadora da língua vernácula, como consta:

[...] os pais de alunos mantêm há anos a aula da comunidade, que tem por fim aprimorar o ensino religioso e a língua vernácula; - que da comissão examinadora do exame da língua vernácula, procedido em dezembro, tomaram parte o 
subprefeito, tenente Lauro José Martins e José Afonso Höher, membro da Comissão do Partido Republicano local; [...] Lomba Grande, 09 de jan. de 1932. (Werle, 2005, p. 148)

Na década de 1930, a Aula Pública Mixta Federal passou a funcionar na região central do bairro. Maria Gersy iniciou seus estudos nessa aula em 1931. Portanto, sua referência formativa é o $5^{\circ}$ ano primário. Quando perguntada, ela assim descreve sua formação: "[...] sou uma professora feito a machado" (Thiesen, 2010), ou seja, sua experiência como aluna foi indispensável no momento em que inicia sua trajetória docente.

Nessa aula Gersy aprendeu as primeiras letras, e nesse lugar também se percebeu professora pela primeira vez. Ela recorda que havia muita disciplina e respeito ao professor. Era necessário levantar a mão e aguardar a vez para falar. Conta que havia muitos alunos, uns auxiliavam os outros, e todos demonstravam muito interesse pela aprendizagem (Souza; Grazziotin, 2012).

O último registro referente à frequência como aluna na Aula Pública Mixta Federal data de 1937, quando, em 30 de setembro, ela foi eliminada da lista de chamada. A chamada de 1931 registra 45 alunos, entre eles Ilse Scherer, Esly Müller, Herta Schüch, Bertholdo Haubert, Augusto Romano, Oscar Strack, Ernesto Ely etc. (Chamada..., 1930).

A instrução pública, na municipalidade, estava em destaque em 1940. Na "Revista do Ensino, ${ }^{14}$ órgão de divulgação sob o patrocínio da Secretaria da Educação e Saúde Pública do Estado do Rio Grande do Sul, publicou em o n. 11, vol. 3, a bela síntese [...]" (O 5 de Abril,1940c, p. 1). A educação ostentava o status de progresso, bem como elevaria o nível cultural da população por meio da escola e de seu processo de ampliação, eliminando o "mal da ignorância". Em Lomba Grande havia "[...] 12 aulas federais, estaduais e municipais, com a matrícula total de 422, para uma população de 4.000 alunos" (idem, ibidem), o que representa o atendimento de apenas $10 \%$ da população em idade escolarizada. Nesse sentido, a iniciativa do governo municipal consistia na

[...] ação eficiente [...] combinada dos poderes públicos e dos particulares, da sincronia de esforços orientados pelos supremos interesses coletivos, é justo asperar a consolidação e a afirmação das nossas carateristicas distintivas de povo livre e realizador, das nossas prerrogativas e ideais de cultura. (idem, ibidem)

Em 1940, também as aulas passaram a ser inspecionadas ${ }^{15}$ por fiscais municipais, quando esse cargo foi criado pelo governo da municipalidade. Tal cargo, fiscal

14 Para um estudo aprofundado sobre esse assunto, ver Bastos (1997).

15 Diferente das aulas do "mestre-escola do império", sem formação específica e com bastante autonomia, a complexa estrutura pedagógica instituída pelos grupos escolares era administrada na unidade de ensino por um diretor e monitorada por inspetores regionais e chefes escolares, que procuravam efetivar as determinações normativas do Estado (Teive; Dallabrida, 2011). 
do ensino, ${ }^{16}$ poderia ser exercido pelas professoras municipais, a critério do governo municipal (Novo Hamburgo, 1940a). E importante ressaltar que na década de 1940, Novo Hamburgo foi temporariamente sede da 2a Delegacia Regional de Ensino. ${ }^{17}$

A tendência centralizadora do governo de Getúlio Vargas, entre 1930 e 1945, caracterizou-se pela nomeação de interventores que governavam os estados sob o controle dos Departamentos Administrativos estaduais, cujos membros eram nomeados pelo presidente da República. Nesse período, com a medida de dissolução do Congresso Nacional e das assembleias estaduais e municipais, Vargas suspende as garantias constitucionais e assume plenos poderes, passando a legislar por meio de decretos. ${ }^{18}$ As diretrizes, os regimentos e os regulamentos atendiam ao propósito de constituição de uma cultura nacional, sobretudo transformar o homem em sujeito que valorizasse, vivesse e servisse à nação (Baia Horta, 2010).

Quanto às Aulas Reunidas Municipais e Estaduais, Gersy recorda:

O pai já era professor na localidade e em outras localidades e tinha classe em muitas Aulas. Então, ele foi falar com a Nair Becker, na Delegacia de Ensino do Estado, para unir as Aulas Públicas, e aí ele formou a escola que se chamou "Escolas Reunidas no 5 ". Onde iniciou, hoje, é uma residência particular. Pertencia a D. Julieta Bohrer. Hoje pertence ao Sr. João Pereira. (Thiesen, 2010)

A professora Maria Gersy desenvolveu sua trajetória em diferentes localidades, porém, neste texto destacamos o momento inicial, quando ela inicia sua vida de

16 Analisando o registro do ponto dos funcionários municipais de Novo Hamburgo, entre 1918 e 1955, constata-se que a professora Ruth Altmayer assume como inspetora das escolas municipais em 1941. Além dela, Luiza Teixeira Lauffer, em 1942 (atualmente, uma instituição de ensino estadual em Novo Hamburgo homenageia essa professora atribuindo seu nome à instituição). A professora Flávia Schüler inaugura o cargo de orientadora do ensino e/ou de responsável pelo Departamento da Educação em Novo Hamburgo, exercido entre 1949 e 1951. A partir de 1952, entra o advogado Parahim Pinheiro Machado Lustosa, que até a década de 1970 ocupara em diferentes períodos esse cargo (Registro..., 1945).

17 Em abril de 1939, a 2a Delegacia Regional de Ensino compreendia os seguintes municípios: Novo Hamburgo, São Leopoldo, São Sebastião do Caí, Montenegro, Taquara e São Francisco de Paula. Abrangia "[...] 109 Escolas Estaduais Isoladas; 3 Escolas Reunidas; 228 Escolas Particulares; - Total 373. [...] 357 professores estaduais e 251 professores particulares [...]" (O 5 de Abril, 1942, p. 3). Ela foi criada pelo "[...] decreto 7.641 de 28-12-1938, foi Instalada em abril de 1939 [...]" (O 5 de Abril, 1942, p. 3). O estado do Rio Grande do Sul encontrava-se dividido em dez regióes escolares. A principal finalidade das delegacias estava em atender às demandas que a possibilidade do ensino público constituía, no estado, na década de 1930 . O atendimento objetivava descentralizar.

18 Cury (C. R. J., 2010) indica que, com o Governo Provisório (1930-1934), o exercício legislativo foi feito pelo Executivo mediante decretos, leis e regulamentos. No período que vai de 1934 a 1937, o instrumento legal utilizado pelo governo federal serão as leis ordinárias e os decretos do Poder Legislativo, editados com força de lei. Durante o Estado Novo (1937-1945), a atividade legislativa era exercida pelo Poder Executivo por meio de decreto-lei. Apenas com a Constituição de 1946, passa-se a utilizar a sequência numérica nas leis e decretos, como é até hoje. Cabe ressaltar que, entre 1965 e 1988, a ditadura militar reintroduziu o decreto-lei. 
professora, primeiro como auxiliar, em 1940, nas Aulas Reunidas Municipais e Estaduais - Aulas Reunidas no 5 e, posteriormente, no Grupo Escolar de Lomba Grande.

O início de sua trajetória foi como professora auxiliar, no $1^{\mathrm{o}}$ ano, junto de seu pai, que, além de professor da $1^{\text {a }}$ classe, também exercia a função de regente. ${ }^{19}$ Ela recorda que ficava a maior parte do tempo sozinha com os alunos, pois o professor José Afonso necessitava "socorrer" constantemente a professora Anália Flores, do $3^{\circ}$ ano. "[...] a professora do $3^{\circ}$ ano [...] D. Anália, [...] não conseguia impor respeito para os aluninhos, então papai vivia lá, e eu sozinha com aquela turminha [...]" (idem, ibidem).

A conduta dos alunos refletia a política "civilizadora" e "modular" que se traduziu nas inúmeras iniciativas que o governo republicano. Posteriormente, a ditadura do governo Vargas imprimiu, com o nacionalismo, a pretensão de homogeneizar e padronizar o comportamento, atitudes em prol de uma pátria única, forte e saudável (Cury, C. R. J., 2010).

Quanto à forma de ingresso no magistério, recorda: "fiz um examezinho de suficiência e já comecei como professora municipal” (Thiesen, 2010), como auxiliar do professor José Afonso Höher. No ponto dos funcionários municipais de Novo Hamburgo constam, nas páginas 75 e 76, detalhes sobre a vida funcional de Maria Gersy, indicando quando ela começou a trabalhar. "Conforme consta do Requerimento n. 2349 de 27.8 .51 e informações a requerente presta serviços públicos desde 21.7.1940" (Registro, 1945, p. 75). A mesma informação confere com a inclusão de "Gersy" M. Höher, a partir de 21 de julho de 1940, no caderno ponto da Aula Pública Mixta Federal (Chamada..., 1930, p. 85). Em 1940, na região rural, as Aulas Reunidas originaram o Grupo Escolar de Lomba Grande, que, em 1942, passou a chamar-se Madre Benícia, em função de sua patrona.

As escolas reunidas previstas em legislação específica poderiam ser criadas nos lugares em que, em virtude da densidade da população, houvesse mais de duas escolas isoladas (Teive; Dallabrida, 2011). A ação conjunta do Estado e do município, em Novo Hamburgo, resultou em ações que se converteram no aprimoramento de algumas instituições escolares, como se observa nesse relato do jornal $O 5$ de Abril (1940b, p. 2):

[...] verificou o snr. Prefeito Odon Cavalcanti, ser de urgente necessidade de alojar mais confortável e higienicamente as aulas da sede distrital, que funcionavam em prédios inadequados. [...]. Por esse contrato ficou à disposição da Prefeitura de Novo Hamburgo um grande prédio de material, abandonado há mais de dez anos. A prefeitura por sua vês faria uma remodelação integral nesse mesmo prédio, destinando-o às Aulas Reunidas, da sede do distrito. Essa total remodelação foi feita sob a orientação da Delegacia da Secretaria da Educação

19 De acordo com Werle (2005), nas Aulas, nas Aulas Reunidas as responsabilidades gestoras eram do regente. Para Bencostta (2005), com os grupos escolares se populariza a figura do diretor. 
com sede em São Leopoldo. [...] Dona Nair Becker, Orientadora, desempenhando atualmente a Delegacia Regional [...]. O prédio que é murado em torno, fica sobre uma linda coxilha no centro da sede e ao lado da igreja católica. As cercanias estavam repletas do povo lomba-grandense. Após festiva recepção das autoridades, deu-se inicio à solenidade da inauguração com o hino nacional, cantado por 200 crianças que, uniformisados, estavam formadas em frente do prédio. Seguiu-se o discurso de recepção, proferido pela interessante menina Iraci Bohrer, que se saiu de sua missão com muito brilho, sendo entusiasticamente aplaudida. Seguiram-se os seguintes números do programa: Hino á Bandeira; poesia "As Aulas Reunidas"dita pela aluna Clotilde Enck.Hino áIndependencia. Poesia "A Pátria" pelo aluno A. Machado.

A data festiva da inauguração das aulas que abrigariam o grupo escolar demonstra o sentimento nacionalista, característico desse período. As escolas, por meio de seus professores, representantes legítimos na constituição dos valores morais, agiriam como "[...] construtores da Nação [...] qualidades morais (boas maneiras, bons antecedentes, bons hábitos [...]) o que comporiam a figura do(a) professor(a) [...]" (Cunha, 2009, p. 239).

Durante a ditadura getulista, com o fechamento das escolas étnicas e sua substituição por escolas públicas, os grupos escolares tiveram um crescimento expressivo, quando começaram a ser fixados também nos espaços rurais dos municípios (Teive; Dallabrida, 2011). Além disso, a igreja foi uma das principais aliadas da escola primária para divulgar os preceitos de civilidade e inspirar o nacionalismo cívico. Pretendia-se levar o Brasil à modernidade moldando os sujeitos e educando-os com condutas, boas maneiras, regras e comportamento ordeiro, cosmopolita, para que tivessem a conduta esperada pela "boa sociedade" (Cunha, 2009).

Ha dez anos, o povo católico desta localidade porfiava pela creação da paróquia, e pela creação de um Grupo Escolar. Graças às S. Exas. Os snrs. Arcebispo D. João Becker e Dr. Odon Cavalcanti, DD. Prefeito da Comuna de Novo Hamburgo, fizeram das promessas a realidade. S. Excia. O snr. Dr. Odon Cavalcanti, intervindo na questão educacional local, conseguiu de S. Excia. Rvdo. Snr. Arcebispo a permissão para adatar o salão da comunidade Católica, á Aulas Reunidas. Feitas as divisões, alem de duas boas galerias, foram organizadas cinco salas, as quais podem comportar 250 alunos. Todas as salas tem luz direta, e ainda, para acautelar a boa marcha dos trabalhos, em dias nublosos, foram instaladas três clarabóias, que fornecem claridade em abundancia. É voz corrente que este melhoramento, trará grandes benefícios á mocidade estudiosa, pois serão aproveitados para o ensino 5 professores, trabalho que era feito apenas por quatro, dois públicos e dois paroquiais. Assim, divididos os alunos que para quatro professores foi superlotar suas aulas, reverterá o tempo e as lições ministradas em melhor proveito do aluno. A inauguração do novo edifício escolar, que provisoriamente foi marcada para o dia 14 de julho, ainda está dependendo de certas circunstancias. [...]. (O 5 de Abril, 1940a, p. 4) 
No Estado Novo de Vargas, a educação aparece como um dispositivo tutelar para melhoria das condições de vida da população urbana e rural, bem como instrumento para nacionalizar as populações de origem estrangeira nas colônias dos habitantes do interior do país (Baia Horta, 2010). Esse aspecto percebe-se no relato da inauguração, dando ênfase às claraboias e ao aperfeiçoamento do prédio que abrigaria o grupo escolar. A política de Vargas, tanto no discurso quanto na legislação, pretendia colocar o sistema educacional a serviço da implantação de um governo autoritário. Dessa forma, a concepção da educação seria um problema nacional, por meio da ligação entre educação e saúde, com ênfase na educação moral.

A reunião de escolas - tanto das Aulas Reunidas quanto, principalmente, dos grupos escolares - trazia todos os princípios fundamentais que propiciaram as mudanças no ensino primário, especialmente no que se refere à promoção de uma nova cultura escolar (Souza, 1998). O grupo escolar representou a grande transformação do ensino primário. Do ponto de vista pedagógico, ele diferenciava-se radicalmente da escola isolada por criar a seriação do ensino primário de quatro anos, sendo que cada série tinha um professor, fato que implicava a definição e a ordenação determinada dos saberes escolares nos programas de ensino, bem como o ensino simultâneo (Bencostta, 2005).

Em 1942, quando as aulas do grupo escolar de Lomba Grande transformaram-se, receberam o nome de Madre Benícia. Gersy foi efetivada como professora do primeiro jardim de infância instalado na localidade, sendo designada, como consta, para o exercício nas: "[...] Aulas Reunidas estaduais e municipais [...], para reger o Jardim de Infância Municipal ‘Getúlio Vargas' [...]” (Novo Hamburgo, 1942, p. 1, grifo do original). Ela também rememora:

[...] eu fui parar no jardim da infância Dr. Getúlio Vargas, era no mesmo edifício, só numa sala, o mesmo prédio [...]. Tinha quatro mesinhas "larguinhas" e, em cada, seis cadeirinhas [...] ali eu era a grande senhora. Tinha um quadro grande, que foi para a escolinha Humberto de Campos. [...] Um quadro grande assim [mostra com as mãos] do tamanho da parede [...]. (Thiesen, 2010, grifo dos autores)

Gersy rememora com ênfase o grande quadro-negro que havia em sua sala de aula. Observa-se que em Lomba Grande, assim como em outros lugares do país, os recursos materiais e pedagógicos não eram suficientes para atender a todas as escolas. Nesse sentido, o improviso caracterizava as práticas pedagógicas de muitos professores, como Maria Gersy, que se utilizava do quadro-negro para realizar brincadeiras, e também dos recursos naturais para suas aulas.

Ainda no contexto das práticas pedagógicas nas aulas isoladas, a professora Gersy lembrou o aspecto cívico, uma situação que a deixou muito orgulhosa:

Eu tinha o meu jardim da infância, e eles cantavam o hino nacional todinho de fio a pavio. Quando o grupo fazia uma festa, o jardim fazia parte. [...], depois a mamãe me contou: - Gersy, tu nem sabe como eu fiquei faceira [...]. Porque eu, cantando o hino nacional, quando foi passado da primeira pra segunda estrofe, 
com as minhas crianças, o grupo embatucou e quase pararam o hino nacional [...].

E o meu jardim, cantando o hino nacional. Isso, até hoje, eu sinto uma alegria quando eu me lembro [...] e o povo notou! (idem)

Gersy destacou que seus alunos do jardim de infância saíam-se muito bem nas aulas de canto orfeônico. Ela emociona-se ao contar essa prática. Registra que a comunidade presente, na festa cívica alusiva aos festejos da pátria, percebeu que os alunos do canto coral do Grupo Escolar de Lomba Grande "embatucaram", perderam-se na letra do hino nacional, e foram seus alunos que "seguraram" a canção.

Gersy ainda recorda os momentos em que levava os "pequenos" alunos do "Jardim da Infância Getúlio Vargas" até o pátio do Grupo Escolar de Lomba Grande, no gramado ao lado da Igreja Católica São José. Ela sentava os alunos em círculo, permitia que eles brincassem com a terra e delegava tarefas para cada um. Esse exercício constituía a criação de uma rotina, com o ensinamento sobre o "cuidar" em todos os sentidos, o que revelou também sua preocupação docente na preservação da natureza, no aprendizado da convivência em grupo e do cuidado com o próximo. Nessa prática, incluía-se buscar água, preparar a terra para o canteiro, separar as mudas de cravinas, o plantio e a conservação desse espaço por todos os alunos (Souza, 2013).

A nova cultura escolar inaugurada pelos grupos escolares no "viveiro de professores" deveria assegurar-lhe o preparo para produzir o cidadão patriota, prático, higiênico, útil à pátria, o cidadão racional, entendido como aquele que respeita as leis, ama a pátria e confia no progresso social e científico. Os mesmos princípios foram seguidos no que se refere à formação prática da professora, que deveria aprender a educar pelo método de educar, pela observação e imitação de práticas pedagógicas modelo (Teive; Dallabrida, 2011).

Em diferentes tempos e com intensidades variadas, durante a Primeira República, o grupo escolar disseminou-se nos estados da federação brasileira como a escola da República por excelência. Apropriação do modelo de escola graduada que circulava no mundo ocidental desde a segunda metade do século XIX, o grupo escolar no Brasil plasmou o ensino primário, que, apesar de algumas mudanças, permaneceu até o início da década de 1970, nas Aulas Isoladas (multisseriadas), quando, por força da lei n. 5.692/1971, foi suprimido do sistema nacional de ensino (idem).

\section{CONSIDERAÇÕES FINAIS}

As pesquisas de história da educação contribuem para se pensar os processos, mudanças e continuidades das ações dos educadores no tempo, participando criticamente na renovação da escola e da pedagogia. Dessa forma, a partir das memórias do seu tempo de aluna e de início da sua vida de professora, foi possível conhecer e compreender um pouco mais sobre o processo de escolarização pública em Lomba Grande, Novo Hamburgo, RS, nas primeiras décadas do século XX.

As memórias de práticas da professora Gersy recompõem um cenário educacional que se destaca no conjunto de municípios do Vale do Sinos. Evidencia a 
prática do "comunitarismo"(Dreher, 2008), expressão que se traduz na organização de um modo de viver em comunidade, de um ritmo cotidiano impresso pelos diferentes grupos que constituíram a população desse lugar. Além disso, caracteriza a produção de uma cultura local identificada com o rural, porém que identifica e acompanha os sinais de progresso que, na década de 1930, projetavam-se na sede do município. A saúde, higiene e educação, como grandes elementos de uma transformação cultural nacional, ecoam também nas reivindicações dos lombagrandenses, tanto nas memórias dos documentos escritos analisados como nas da professora Gersy.

A cultura do rural, do modo simples, porém autêntico de construir práticas necessárias para a vida cotidiana entrecruza-se com as representações e valores urbanísticos de um período promissor que se inicia no âmbito nacional, com a pretensão de incluir o país no rol das nações desenvolvidas. As práticas pedagógicas perseguem um interesse político nacional, mesmo que revestidas de intenções e ações próprias dos sujeitos do lugar. Se a alfabetização, para os imigrantes alemães, representava certa autonomia com o conhecimento das escrituras bíblicas e garantia minimamente uma autonomia de pensamento, no início do século XX a ampliação dessa prática deveria garantir a máxima do republicanismo e contribuir para elevar o nível cultural da população.

Em 1943, no município de Novo Hamburgo, havia 35 escolas, entre estaduais e municipais, com o total de 1.477 alunos atendidos (Petry, 1959) e uma população de que representava 19.250 mil habitantes (Schütz, 2001), sendo que $43 \%$ destes viviam no espaço rural, e apenas $10 \%$ dos alunos em idade escolar frequentavam a escola. Considerando a estatística escolar de 1927 (Petry, 1959), a ampliação no número de instituições não compreendeu o acesso à escola tanto no espaço rural quanto urbano. Além disso, o movimento local de ampliação da oferta do ensino permite relativizar o aspecto da política de substituição das escolas comunitárias pelas escolas "nacionalistas" (Arendt, 2008).

Investigar a escola primária em Novo Hamburgo, especialmente a presença do ensino público em regiões rurais de colonização germânica, é reconhecer o processo e a evolução do sentido que o público adquire no sistema de governo republicano (Saviani, 2010). Identificar a presença das políticas de ensino das aulas (escolas) municipais exige reconhecer que, até a década de 1930, a ação do governo municipal estava vinculada muito mais às políticas dos estados federados do que uma ação local de constituição das políticas educacionais. A ação conjunta da administração municipal com o governo estadual e também federal, por meio de subvenções, permite identificar, mesmo que timidamente, o acesso à escola pública pela população rural.

Observa-se que em Lomba Grande, já no século XIX, as Aulas Isoladas, tanto as federais quanto as municipais e as subvencionadas estaduais, junto com as aulas da comunidade católica e da evangélica, favoreceram para que esse bairro rural ingressasse na modernidade pedagógica dos grupos escolares, o que talvez esteja associado com a política de fechamento de escolas comunitárias, instituída com o Estado Novo de Vargas (Souza, 2012c). Cabe ressaltar que o propósito deste estudo é o de problematizar o modo como essa comunidade - resultado não apenas da 
etnia alemã, mas de um encontro híbrido de grupos sociais - articulou-se para que a realidade escolar acontecesse (Canclini, 2008).

A proposta de um ensino público unitário e nacional contribuiria no sentido de fazer desaparecer as ideias locais, principalmente nas áreas de colonização de imigração italiana e alemã, fazendo ressaltar os limites da ideia nacional do ensino primário (Baia Horta, 2010). Porém os primórdios do grupo escolar vinculam-se às ações do professor José Afonso Höher, pai de Gersy - de origem alemã -, que foi o primeiro regente das Aulas Reunidas n. 5 e Aulas Reunidas n. 24 (municipais e estaduais), que originaram o Grupo Escolar de Lomba Grande (Souza, 2012c).

Os grupos escolares no Brasil em meados do século XX, em compasso com o processo de urbanização e democratização do ensino público, deveriam ter substituído a forma artesanal em que se configuravam as escolas primárias. No entanto, há de considerar a participação de outros tipos de escolas primárias nesse processo, especialmente das Escolas Isoladas, que até a década de 1970 representaram a forma de escolarização possível, principalmente nos espaços rurais como em Lomba Grande.

\section{REFERÊNCIAS}

Acıoli, V. L. C. A escrita no Brasil Colônia: um guia para leitura de documentos manuscritos. Recife: Editora Universitária, 1994.

Almeida, D. B. Vozes esquecidas em horizontes rurais: histórias de professores. 2001.245f. Dissertação (Mestrado em Educação) - Universidade Federal do Rio Grande do Sul, Porto Alegre, 2001.

Memórias da rural: narrativas da experiência educativa de uma escola normal rural pública (1950-1960). 2007.272f. Tese (Doutorado em Educação) - Universidade Federal do Rio Grande do Sul, Porto Alegre, 2007.

Almeida, J. S. Apresentação. In: Saviani, D.; Almeida, J. S; Souza, R. F.; Valdemarin, V.T. O legado educacional do século XX no Brasil. 2. ed. Campinas: Autores Associados, 2006. Amado, J.; Ferreira, M. M. Apresentação.In:___.;___. (Orgs.). Usos E a abusos da história oral. 5. ed. Rio de Janeiro: FGV, 2002.

O grande mentiroso: tradição, veracidade e imaginação em história oral. História, Assis: UNESP, n. 14, p. 125-136, 1995. (Projeto História)

Arendt, I. Educação, religião e identidade étnica: o Allgemeine Lehrerzeitung e a escola evangélica no Rio Grande do Sul. São Leopoldo: Oikos, 2008.

Baia Horta, J. S. A política educacional no Estado Novo. In: Saviani, D. (Org.). Estado e políticas educacionais na história da educação brasileira. Vitória: EDUFES, 2010.

Bastos, M. H. C. As revistas pedagógicas e a atualização do professor: a Revista do Ensino do Rio Grande do Sul (1951-1992). In: Catani, D. B.; Bastos, M. H. C. (Orgs.). Educação em revistas: a imprensa pedagógica e a história da educação. São Paulo: Escrituras, 1997. p. 47-76.

Bencostta, M. L. A. Arquitetura e espaço escolar: o exemplo dos primeiros grupos escolares de Curitiba (1903-1928). In: Bencostta, M. L.A.(Org.). História da educação, arquitetura e espaço escolar. São Paulo: Cortez, 2005. 
Borges, M. E. L. História \&̊ fotografia. Belo Horizonte: Autêntica, 2011.

Burke, P. O que é história cultural? Tradução de Sérgio Góes de Paula. Rio de Janeiro: Jorge Zahar, 2005.

Canclini, N. G. Culturas hibridas: estratégias para entrar e sair da modernidade. Tradução de Heloísa Pezza Cintrão e Ana Regina Lessa; Tradução da introdução de Gênese Andrade. 4. ed. São Paulo: Editora da Universidade de São Paulo, 2008.

Certeau, M. A escrita da história. Tradução de Maria de Lourdes Menezes; Revisão técnica de Arno Vogel. 3. ed. Rio de Janeiro: Forense, 2011.

Chartier, R. À beira da falésia: a história entre incertezas e inquietude. Tradução de Patrícia Chittoni Ramos. Porto Alegre: UFRGS, 2002.

Cunha, M. T. S. Saberes impressos, escritas da civilidade e impressos educacionais (década de 1930 a 1960). In: Yazbeck, C.; Rocha, M. B. M. (Orgs.). Cultura e história da educação: intelectuais, legislação, cultura escolar e imprensa. Juiz de Fora: Editora UFJF, 2009.

Cury, C. R. J. A educação nas constituições brasileiras. In: Stephanou, M.; Bastos, M. H. C. (Orgs.). História e memórias da educação no Brasil: século XIX. Rio de Janeiro: Vozes, 2009.v. 3.

Reformas educacionais no Brasil. In: SAviani, D. (Org.). Estado e politicas educacionais na história da educação brasileira. Vitória: EDUFES, 2010.

Cury, C. E. Desafios da pesquisa com cultura escolar na documentação da Parahyba oitocentista. In: Vidal, D. G.; Schwartz, C. M. (Orgs.). História das culturas escolares no Brasil. Vitória: EDUFES, 2010.

Dosse, F. História e ciências sociais. Tradução de Fernanda Abreu. Bauru; São Paulo: EDUSC, 2004.

Dreher, M. N. Breve história do ensino privado gaúcho. São Leopoldo: Oikos, 2008.

Fischer, B. T. D. Professoras: histórias e discursos de um passado presente. Pelotas: Seiva, 2005.

Galves, M. C. Pequena imprensa e poder político: pensando os jornais locais como objeto e fonte de pesquisa. Outros Tempos, São Luís: Universidade Estadual do Maranhão, v. 1, p. 66-73, 2004. Disponível em: <http://www.outrostempos.uema.br/volume01/ vol01art05.pdf>. Acesso em: 21 jul. 2012.

Gertz, R. O Estado Novo no Rio Grande do Sul. Passo Fundo: Editora da Universidade de Passo Fundo, 2005.

Ghirardelli Junior, P. História da educação. São Paulo: Cortez, 2009.

Halbwachs, M. A memória coletiva. São Paulo: Centauro, 2006.

Kerber, A.; Schemes, C.; Prodanov, C. C. Memórias das práticas educativas durante o primeiro Governo Vargas na cidade de Novo Hamburgo, RS. Revista Brasileira de História da Educação, Campinas: UNICAMP, v. 12, n. 2 (29), p.139-170, maio/ago. 2012. Kreutz, L. Escolas comunitárias de imigrantes no Brasil: instâncias de coordenação e estruturas de apoio. Revista Brasileira de Educação, Rio de Janeiro: ANPEd; Campinas: Autores Associados, v. 1, n. 15, p. 159-176, 2001. 
Um pastor elaborando e imprimindo material didático: desvio de função? In: Bastos, M. H. C.; Tambara, E.; Kreutz, L. (Orgs.). Histórias e memórias da educação do Rio Grande do Sul. Pelotas: Seiva, 2002.

.Escolas étnicas na história da educação brasileira: a contribuição dos imigrantes. In: Stephanou, M.; Bastos, M.H. C. (Orgs.) História e memórias da educação no Brasil: século XIX. Rio de Janeiro: Vozes, 2009. v. 2.

Luchese, T. A.; Kreutz, L. Das escolas de improviso às escolas planejadas: um olhar sobre os espaços escolares da região colonial italiana, Rio Grande do Sul. Revista Brasileira de História da Educação, Campinas: UNICAMP, v. 12, n. 2(29), p. 45-75, maio/ago. 2012.

Martins, R. P. A produção calçadista em Novo Hamburgo e no Vale do Rio do Sinos na industrialização brasileira: exportação, inserção comercial e política externa: 1969-1979. 2011. 198f. Tese (Doutorado em História) - Pontifícia Universidade Católica do Rio Grande do Sul, Porto Alegre, 2011.

Nóvoa, A. Prefácio. In: Monarcha, C. (Org.). História da educação brasileira: formação do campo. 2. ed. Ijuí: Unijuí, 2005.

Petry, L. O município de Novo Hamburgo: monografia. 1. ed. São Leopoldo: Oficinas Gráficas Rotermund, 1959.

Pimentel, A. O método da análise documental: seu uso numa pesquisa historiográfica. Cadernos de Pesquisa, São Paulo: Fundação Carlos Chagas; Campinas: Autores Associados, n. 114, p. 179-195, nov. 2001. Disponível em: <http://www.scielo.br/scielo. php?pid=S0100-15742001000300008\&script=sci_arttext>. Acesso em: 21 jul. 2012.

Prins, G. História oral. In: Burke, P. (Org.). A escrita da história: novas perspectivas. Tradução de Magda Lopes. São Paulo: UNESP, 1992.

Rocha, S. (Org.). Escola cidadã em Novo Hamburgo: participação, qualidade e aprendizagem. Novo Hamburgo: Prefeitura Municipal, 2012.

Ribeiro, M. Pedagogia da alternância na educação rural/do campo: projetos em disputa. Educação e Pesquisa, São Paulo: USP, v. 34, n. 1, p. 27-46, jan./abr. 2008.

Saviani, D. O Estado e a promiscuidade entre o público e o privado na história da educação brasileira. In:___. (Org.). Estado epolíticas educacionais na história da educação brasileira. Vitória: EDUFES, 2010. p. 17-44.

Schemes, C. Pedro Adams Filho: empreendedorismo, indústria calçadista e emancipação de Novo Hamburgo (1901-1935). 2006. 446f. Tese (Doutorado em História) - Pontíficia Universidade Católica do Rio Grande do Sul, Porto Alegre, 2006.

Schimmelpfeng, R.M. Retocando imagens: a Escola Alemã/Colégio Progresso (1930-1945). In: Bencostta, M. L. A. (Org.). História da educação, arquitetura e espaço escolar. São Paulo: Cortez, 2005.

Schüтz, L.M. M. Novo Hamburgo, sua história, sua gente. Novo Hamburgo: [s.n.], 2001. Selbach, J. F. Novo Hamburgo 1927-1997: os espaços de sociabilidade na gangorra da modernidade. 1999. 370f. Dissertação (Mestrado em Arquitetura e Urbanismo) Universidade Federal do Rio Grande do Sul, Porto Alegre, 1999. 
Souza, J. E. A "Hora da História": memórias e possibilidades no currículo da escola multisseriada (Novo Hamburgo/RS - 1952/1969). História E Ensino, Londrina: Universidade Estadual de Londrina, v. 18, p. 103-124, 2012a.

E. Memórias de professores: histórias de ensino em Novo Hamburgo/RS (1940-2009). Porto Alegre: Evangraf, 2012b.

. Memórias evocadas: notas sobre o grupo escolar de Lomba Grande - Novo Hamburgo/RS - (1942). In: Ramos, E. H. C. L.; Arendt, I. C.; Witt, M. A. (Orgs.). A história da imigração e sua(s) escrita(s). São Leopoldo: Oikos, 2012c. p. 765-781.

A festa da pátria: memórias cívicas na área rural de Novo Hamburgo/RS (1930-1970). Artelogie, França (on-line), n. 4, 19 jan. 2013.

.; Fischer, B. T. D. Memórias do ensino em Novo Hamburgo: documentos e acervos (1940-2009). NH na Escola, Novo Hamburgo: Grupo Editorial Sinos, p. 2, 25 out. 2012.

; Grazziotin, L. S. S. Memórias evocadas: imagens recompondo as aulas isoladas em Novo Hamburgo/RS (1913 a 1952). Aedos: revista do corpo discente do Programa de Pós-Graduação em História da UFRGS (on-line), v. 4, p. 652-674, 2012.

Souza, R. F. Templos de civilização: a implantação da escola primária graduada no estado de São Paulo (1890-1910). São Paulo: Editora UNESP, 1998.

. Lições da escola primária. In: Saviani, D.; Almeida, J. S; Souza, R. F.; Valdemarin, V.T.2. ed. O legado educacional do século XX no Brasil. Campinas: Autores Associados, 2006.

Stephanou, M. Nem uma coisa, nem outra ou nenhumas. Reinvenções e reminiscências escolares. A modo de prefácio. In: Fischer, B. T.D. (Org.). Tempos de escola: memórias. São Leopoldo: Oikos; Brasília: Liber Livro, 2011.

Teive, G. M. G.; Dallabrida, N. A escola da República: os grupos escolares e a modernização do ensino primário em Santa Catarina (1911-1918). São Paulo: Mercado de Letras, 2011.

Tномлом, A. Recompondo a memória: questões sobre a relação entre a história oral e as memórias. Projeto História, São Paulo: EDUC, n. 15, p. 51-84, abr. 1997.

WERLE, F. O. C. O nacional e o local: ingerência e permeabilidade na educação brasileira. Bragança Paulista: Editora Universidade São Francisco, 2005.

\section{FONTES}

Aula Particular da Comunidade Evangélica.Lomba Grande, 1927-1934. Localizado na residência da senhora Edelsi Quadros, 6 de janeiro de 2012. Lomba Grande (São Leopoldo), 1927.

BOH RER, T. Entrevista oral sobre a trajetória de vida e docente em classes multisseriadas em Lomba Grande. Entrevista concedida ao autor. Novo Hamburgo, 21 de abril de 2010 e 3 de maio de 2010.

Chamada e Ponto da Aula pública mixta federal, 1930-1942. Arquivo Passivo do Instituto Estadual de Educação Madre Benícia. Novo Hamburgo, 1930. 
Livro de Chamada dos alunNos da aula municipal mixta da Lomba Grande. Lomba Grande, $1^{\circ}$ de agosto de 1913. Localizado na residência da senhora Edelsi Quadros, 6 de janeiro de 2012. Novo Hamburgo, 1913.

Novo Hamburgo. Decreto n. 1, de 2 de janeiro de 1940. Instala o Distrito de Lomba Grande e toma posse dos serviços de sua administração. Novo Hamburgo, 1940a.

. Decreto n. 3, de 2 de março de 1940. Crêa o cargo de fiscal do ensino. Novo Hamburgo, $1940 \mathrm{~b}$.

Decreto n. 16/24, de 19 de abril de 1942. Designa uma professora. Novo Hamburgo, 1942.

Notícias de Lomba Grande. O 5 de Abril, Novo Hamburgo, ano XIV, n. 10, 1940a, 7 de junho de 1940.

. A instrução em Lomba Grande. Inauguração do prédio reformado - caixa escolar assistencia sanitaria e dentaria - outras notas. Novo Hamburgo, n. XIV, n. 18, 1940b, 2 de agosto de 1940.

.A instrução pública em Novo Hamburgo. Novo Hamburgo, ano XIV, n. 25, 1940c, 20 de setembro de 1940.

.2 2a Delegacia Regional de Ensino. Novo Hamburgo, ano XVI, n. 1,5 de abril de 1942.

- Centenário da comunidade evangélica de Lomba Grande. Ano XXI, n. 47, Novo Hamburgo, 20 de fevereiro de 1948.

Registro dos funcionários municipais. Livro ponto dos funcionários municipais de Novo Hamburgo (1945-1955). Localizado no Arquivo Público Municipal de Novo Hamburgo-RS. Novo Hamburgo, 1945. 256p.

Thiesen, M. G. H. Entrevista oral sobre a trajetória de vida e docente em classes multisseriadas em Lomba Grande. Entrevista concedida ao autor. Novo Hamburgo, 23 de abril de 2010 e 13 de maio de 2010.

\section{SOBRE OS AUTORES}

José Edimar de Souza é doutorando em educação pela Universidade do Vale do Rio dos Sinos (UNISINOS).

E-mail:profedimar@gmail.com

Luciane Sgarbi Santos Grazziotin é doutora em educação pela Pontifícia Universidade Católica do Rio Grande do Sul (PUC-RS). Professora da Universidade do Vale do Rio dos Sinos (UNISINOS).

E-mail:1sgarbi@terra.com.br 